\title{
Lumen
}

Selected Proceedings from the Canadian Society for Eighteenth-Century Studies

\section{“Spenser, Ariosto etc.”: Elizabeth Simcoe Reads Canada}

\section{Eric Miller}

Volume 38, 2019

URI : https://id.erudit.org/iderudit/1059272ar

DOI : https://doi.org/10.7202/1059272ar

Aller au sommaire du numéro

Éditeur(s)

Canadian Society for Eighteenth-Century Studies / Société canadienne d'étude du dix-huitième siècle

ISSN

1209-3696 (imprimé)

1927-8284 (numérique)

Découvrir la revue

Citer cet article

Miller, E. (2019). “Spenser, Ariosto etc.”: Elizabeth Simcoe Reads Canada.

Lumen, 38, 53-71. https://doi.org/10.7202/1059272ar d'utilisation que vous pouvez consulter en ligne.

https://apropos.erudit.org/fr/usagers/politique-dutilisation/ 


\title{
"Spenser, Ariosto etc.": Elizabeth Simcoe Reads Canada
}

\author{
ERIC Miller \\ University of Victoria
}

\section{Arabella Fermor and the River St. Lawrence}

J. Ross Robertson published the first edition of what he called The Diary of Mrs. John Graves Simcoe in 1911. It begins with the writer's arrival at the Channel town of Weymouth, Dorsetshire, on 17 September 1791, from where she will embark for British North America. It concludes after her return to England, with her putting up in a Cork Street, London, hotel on 16 October 1796. Mary Quayle Innis's 1965 Mrs. Simcoe's Diary, a fresh transcription of the manuscript, observes the same termini. ${ }^{1}$ Both editors provide notes, but Ross and Innis alike refrain from going beyond bare identification of what Simcoe quotes, refers to, or (in the case of plays) sees. Sometimes they direct the reader to Simcoe's source. Neither editor speculates about the meaning of Elizabeth Simcoe's allusions or how they might illuminate her education, her sensibility, or her construction of Canadian reality. These omissions bear addressing. A closer engagement with two exemplary passages can reveal some of the ways in which Simcoe "settled" her experience artistically, even as it occurred. ${ }^{2}$ She canvasses such topics as history, indigeneity, womanhood and herself as, possibly, a heroine.

1. Elizabeth Simcoe, The Diary of Mrs. John Graves Simcoe, ed. J. Ross Robertson (Toronto; Ontario Publishing, 1934, c1911); Elizabeth Simcoe, Mrs. Simcoe's Diary, ed. Mary Quayle Innis (Toronto: Macmillan, 1965). References are to the Innis edition.

2. Mary Beacock Fryer, Elizabeth Posthuma Simcoe 1762-1850: A Biography (Toronto: Dundurn, 1989) often illuminates cultural contexts for Simcoe's painting and writing. Yet Fryer does not subject the Diary to reading of the kind attempted 
Elizabeth Simcoe was born in England in 1762, married Colonel John Graves Simcoe in 1782, and accompanied him on the post ship H.M. Triton after he was appointed Lieutenant-Governor to the new Province of Upper Canada created by the Canada Act of 1791. On the twelfth of June 1792, she and her husband passed in a set of bateaux out of Lac St. Pierre, a dilation of the St. Lawrence River. They paused at the town of Sorel before continuing upstream toward Montréal. Simcoe writes in her journal:

The situation of Sorrel is so flat, that nothing relieves the prospect but the Masts of a few small Ships building here. We dined in the boat \& the heat was excessive but the Evening calm \& so very pleasant as almost to persuade me it is worth while to cross the Atlantic for the pleasure of voyaging on this delightful Lake-like River, the setting sun reflecting the deepest shades from the shores \& throwing rich tints on the water. This repose is finely accompanied by the Songs of the Batteaux men, which accord in time to the regular stroke of the Oars \& have the best effect imaginable. No wonder Spenser, Ariosto etc., dwelt on the delight of sailing in a Boat on Lakes, and make it approach to Islands of Delight. After a day of fatigue \& where strong Currents require peculiar exertion they sing incessantly \& give a more regular stroke with the oars, when accompanied by the tunes. This practice has been learned from Grand Voyageurs, or Canadians who are hired by the N. West Company to take Canoes to the Grand Portage beyond Lake Superior. Now \& then an Indian Halloo breaks the often repeated notes \& enlivens the Sound. We admired one of their songs Trois filles d'un Prince so much that we desired it to be often repeated. (63-64)

This passage reflects Elizabeth Simcoe's wilful hedonism as well as her syncretic imagination. What she wants and what she derives is pleasure. What kind? She reckons her evening "almost" agreeable enough to justify the discomfort of faring overseas. This verdict modifies a passage from Frances Brooke's 1769 epistolary novel The History of Emily Montague. In that fiction, young Arabella Fermor (a heroine

here. The same can be said of, Mary Beacock Fryer and Christopher Dracott, John Graves Simcoe, 1752-1806: A Biography (Toronto: Dundurn, 1998); and Mary Beacock Fryer, "Our Young Soldier": Lieutenant Francis Simcoe 6 June 1791-6 April 1812 (Toronto: Dundurn, 1996). Denis Longchamps's PhD thesis, "Elizabeth Simcoe $(1762-1850)$ : une amateure et intellectuelle anglaise dans les Canadas. Son oeuvre écrite et dessinée, et le projet colonial" (Concordia, 2009), addresses Simcoe’s extant graphic work. 
bearing a name Brooke borrowed from the circle of Alexander Pope ${ }^{3}$ ) reports from Silleri, near Québec City: "the loveliness of this fairy scene alone more than pays the fatigues of my voyage; and, if I ever murmur at having crossed the Atlantic, remind me I have seen the River Montmorenci." Captain George Murray's storm-rattled sixthrater had not offered Brooke's reader, Elizabeth Simcoe, an easeful transit from Britain to Lower Canada in September and October 1791. The diarist here enjoys an ironic adaptation of Emily Montague to her own case, while testifying to a fresh and, for her, unprecedented delight. She varies her bliss by the act of recreating her experience as literature and through literature, improvising on a motif from Frances Brooke. Lac St. Pierre, where the St. Lawrence River bulges to sixteen kilometres in breadth, stimulates a knowing tribute to an earlier female writer. ${ }^{5}$ Brooke's Arabella Fermor depicts Montmorenci with François Boucher-like sensuality. She projects multiple presences of her own sex onto the beauty-spot. Comparing the environs to "the abode of the Nereids," Fermor calls "a little island, crowned with flowering shrubs... the throne of the river goddess," and declares "I intend to build a temple here to the charming goddess of laziness." In less stable circumstances, writing offers the itinerant Simcoe delectation to compound her June evenings-analogously as the bateaumen's song enhances nightfall's visible (though voiceless) transfigurations. Simcoe's prior reading of Emily Montague informs the happiness she feels-and makes.

3. The fictional Arabella Fermor shares a name with the dedicatee of The Rape of the Lock; her namesake is said to furnish the model for Belinda in the mock epic. On 29 April 1792, Simcoe explicitly mentions Frances Brooke's novel: “The woods are beautiful \& we went near to Sellery, that pretty vale Emily Montague describes, indeed her account of Quebec appears to me very near the truth" (59).

4. Frances Brooke, The History of Emily Montague (Toronto: McClelland \& Stewart, 2008), 32.

5. The "Fall of Montmorenci" is among the canonical imperial sights enrolled in Scenographia Americana, which went on sale in 1768 , the year before the publication of Emily Montague. See Fred Anderson, The Crucible of War: The Seven Years' War and the Fate of Empire in British North America, 1754-66 (New York: Knopf, 2000), 437 .

6 . Brooke, 31-33. Fermor evokes beings proper to the sea rather than fresh water (Nereids), and she alters the customary sex of river deities (they are conventionally male in antiquity). 
Simcoe was a gifted painter. Her familiarity with the picturesque colours her phrasing. Out of a community of aesthetic expectation, other writers of the period independently note scenic and acoustical effects of the kind Simcoe does. Jay Macpherson has observed that Ann Radcliffe, writing in the same period, pioneered a form of fiction in which the major characters function in some respects "as spirits of place." Simcoe's almost daily discipline of sketching and describing makes her flesh-and-blood sister to some of Radcliffe's imaginary personae. Publishing a couple of years later, in 1794, the Gothic novelist has her heroine Emily St. Aubert relish the nocturnal song of gondoliering visitors to Venice. Of young Emily, a reluctant member of Count Montoni's entourage, the narrator of Mysteries of Udolpho records:

In the cool of the evening the party embarked on Montoni's gondola, and rowed out upon the sea. The red glow of sun-set still touched the waves, and lingered in the west, where the melancholy gleam seemed slowly expiring, while the dark blue of the upper aether began to twinkle with stars. Emily sat, given up to pensive and sweet emotions.... As she listened to the measured sound of the oars, and to the remote warblings that came in the breeze, her softened mind returned to the memory of [her father] and to [her beloved] Valancourt.... The last strain of distant music now died in air, for the gondola was far upon the waves, and the party determined to have music of their own. The Count Morano ... snatched up a lute, and struck the chords with the finger of harmony herself, while his voice, a fine tenor, accompanied them in a rondeau full of tender sadness. ${ }^{8}$

7. Jay Macpherson, Spirit of Solitude: Conventions and Continuities in Late Romance (New Haven: Yale, 1982), 54-55.

8. Ann Radcliffe, The Mysteries of Udolpho, ed. Bonamy Dobrée (Oxford: Oxford University Press, 1998), 184. Simcoe herself imagines a fiction featuring an imperilled woman protagonist. On 18 March 1795, she records, "An Express went to Niagara. A person lately crossing Lake Champlain passed a large Hole in the Ice \& an infant alive lying by the side of it. By tracks it appeared as if a Sleigh had fallen in \& it was known a heavy-laden Sleigh with families in it left the country on the opposite shore the day before, probably the Mother threw the Child out as the Sleigh went down. The Gentlemen carried the Infant to Montreal where a subscription was raised for her Maintenance-a good circumstance this for the commencement of a Heroine's life in a Novel" (155). Simcoe may suffuse this anecdote with a sentiment of her own survival. Her father Lieutenant-Colonel Thomas Gwillim had died on service in Germany while her mother, also Elizabeth, still carried her. A few hours after giving birth, the widow Gwillim herself expired. To be tossed onto ice offers a 
Fictitious Emily St. Aubert teaches Radcliffe's reader to redeem from fear and sadness a plus (even over-plus) of sensuous replenishment. Like Simcoe, an adept of the picturesque, Radcliffe adopts an ekphrastic manner, as though copying a lost picture by Élisabeth Vigée Le Brun or Angelica Kauffmann.

Elizabeth Simcoe's comparable felicity (as she sketches it on her page) gains its distinct profile by the influence of contrast. Insipid flatness vitiates the topography of Sorel. A sultry "day of fatigue" has enervated everyone, especially the bateaumen. Now dusk deepens "shades" and points "tints," visual corollaries of Simcoe's literary allusiveness and of the oarsmen's chorus. 'No static picture-plane, her scene surges. Night intensifies its refreshment; a reserve of masculine energy resonates responsively. As in Radcliffe, a species of soundtrack provokes and sustains the measure that the crew at the sweeps obeys. "Les trois filles d'un prince" is not an English song. Simcoe's crew performs a French poem susceptible to her reading. Under its spell, Simcoe chooses to compare herself and these men and bateaux and the St. Lawrence to the heroic verse that she favours most: Renaissance epic, the work of "Spenser, Ariosto etc." Such anachronistic literary reminiscence recalls and incorporates long reaches of history and geography. In Ludovico Ariosto's romance, which centres on the invasion of Charlemagne's Europe by King Agramant's North African force, the poet, who lived from 1474 to 1533 , marshals personnel diverse in the extreme-Chinese Angelica, Moorish Medor, French Orlando, Circassian Sacripant. ${ }^{10}$ Edmund Spenser (1552-99) contrives in language artificially antique an allegory of courtesy and virtue, as (among many lesser knights obliged to other aims) Prince Arthur goes in quest of his dream bride Gloriana, a flattering avatar of Elizabeth I. Simcoe's

perfect picture of coldness: a hard second delivery into an unwelcoming world. Yet the brute infrangibility of the congealment goes to save the orphaned baby. The tone accidentally resembles both Catherine Morland's and her creator, Jane Austen's, in Northanger Abbey.

9. On 14 March 1794, Simcoe records delight in discovering a certain "Sicilian Mariner's Hymn to the Virgin," another nautical song. I have traced it to The European Magazine and London Review 22 (November 1792); $3^{85}$ (babel.hathitrust. org, accessed 25 August 2017). She even has a military band play it (117). The text is brief: O sanctissima! O piissima! [sic] Dulcis Virgo Maria, Mater amata, intemerata, ora, ora pro nobis, or (to translate): "O most holy! O most pious woman! Sweet maiden Maria, beloved mother, undefiled, pray, pray for us."

10. The historical Charlemagne lived from $742-814$. 
Diary will, a little subsequently, inflect her encounter with Canada with allusion to a further epicist, Torquato Tasso (1544-95), the peer of Spenser and of Ariosto as he focuses on the crusading Duke Godefroy de Bouillon's eleventh-century "deliverance" of Jerusalem from the heathen.

\section{Fierce Wars and Faithful Loves}

Simcoe's bateaumen sing in French because (she explains) they have learned their skill as rowers, with their proficiency in music, from voyageurs serving the North-West Company. Joseph Frobisher and Simon McTavish established this enterprise in 1783 . On 13 June 1792 , the day after listening to multiple renditions of "Les trois filles d'un prince," Simcoe would ride into the city of Montréal in the founder Frobisher's private phaeton. Her husband, the Lieutenant-Governor, though preferring to encourage the cultivation of such crops as flax, conceded the persisting importance of the fur trade. He intended to found Upper Canada's capital at New London (now London, Ontario) as an emporium where "The Indians in all probability would be induced to become carriers of their own peltries, and they would find a ready, contiguous, commodious and equitable mart, honorably advantageous to Government and the community in general, without their becoming a prey to the monopolizing and unprincipled trader." Mattie M.I. Clark tells us that in 1794 "the furs from Niagara, Detroit and Michilimackinac were valued at not more than $£ 100,000 . " 12$ But Clark also quotes a gratified Governor Simcoe reporting around the same time from Kingston, Upper Canada, "The language of the merchants [is] very much altered - the Fur Trade, as I had hoped, seem[s] no longer the principal object of their attention."13 He understood that the trading posts at fortified Détroit and elsewhere along the frontier, still garrisoned by the British though ceded to the Americans in the

11. Major E. B. Littlehales, "Journal from Niagara to Detroit," The Correspondence of Lieut. Governor John Graves Simcoe, ed. E.A. Cruikshank, vol. 1 (Toronto: Ontario Historical Society, 1923): 293.

12. Mattie M.I. Clark, The Positive Side of John Graves Simcoe (Toronto: Forward, 1943), 99 .

13. Ibid. 111. 
1783 Treaty of Paris, must soon be surrendered. He anticipated adjusting the nascent economy of the colony to this inevitable disturbance.

The song that the bateaumen sing on the St. Lawrence hence may epitomize, for Elizabeth Simcoe, what is past or passing away: la Nouvelle France and the great, fading institution of la pelleterie. "Les trois filles d'un prince" derives originally from Bretagne. Like the epics of Edmund Spenser and Ludovico Ariosto, its lyrics emphasize women characters, their thoughts, feelings, and opinions. Spenser's imaginary ladies carry his poem equally with his knights. The Faerie Queene as a whole is dedicated to a monarch who shares Elizabeth's name. Ariosto's aristocratic Orlando Furioso features in its first book "a damsell faire and bright,/Of passing strength but of more passing hew," the man-killing Bradamant: she swiftly overthrows a male challenger, Sacripant. ${ }^{14}$ It is, moreover, the noble Angelica who induces Orlando's delirium and thus supplies Ariosto with his title. On 12 June 1792, on the darkening St. Lawrence River, the bateaumen's commemoration of a prince's three daughters accords with Simcoe's reading, her taste, and her allegiances. She is an avowed and convinced Royalist. Her husband fought in the Queen's Rangers during the American rebellion. The Simcoes know that Louis XVI and Marie Antoinette already live under threat, and for them feel sympathy. ${ }^{15}$ Colonel Simcoe perceives before him the task of securing the future of the British Crown in North America, despite recent open warfare between the expansive United States and the self-styled United Indian Nations of the Ohio River Valley, a confederacy comprising in its league the Shawnees, Miamis and Potawatamis, among others.

So what did Elizabeth Simcoe hear? How does the rowers' song go? The version recorded in the 1859 Recueil de chansons canadiennes et françaises runs (under the title "Le Pommier Doux"):

Par derrièr' chez mon père,

Vole, mon coeur, vole!

Par derrièr' chez mon père,
Behind my father's home

Soar, my heart, soar!

Behind my father's house

14. Lodovico Ariosto, Orlando Furioso; Translated into English Historical Verse by Sir John Harington (1591), ed. Robert McNulty (Oxford: Clarendon, 1972), $1.69,8 / 1.70,1$.

15. On 1 March 1794, Simcoe reports, "The News received of the death of the Queen of France. Orders given out for Mourning in which everyone appeared this Evening \& the dance was postponed" (116). 
Il y a un pommier doux;

Il y a un pommier doux, Tout doux,

Il y a un pommier doux.

La feuille en est verte

Vole, mon coeur, vole!

Et le fruit en est doux,

Tout doux.

Trois filles d'un prince,

Vole, mon coeur, vole!

S'sont endormi' dessous,

Tout doux.

La plus jeun' se réveille, Vole, mon coeur, vole!

Ma soeur, voilà le jour, Tout doux.

Ce n'est qu'une étoile, Vole, mon coeur, vole!

Qu'éclaire nos amours, Tout doux.

Nos amants sont en guerre, Vole, mon coeur, vole!

Qui combattent pour nous, Tout doux.

S'ils gagnent la bataille, Vole, mon coeur, vole! Ils auront nos amours, Tout doux.

Qu'ils perd'nt ou qu'ils gagnent, If they win the fight, Vole, mon coeur, vole! Ils les auront toujours, Tout doux. ${ }^{16}$
There is an orchard sweet;

There is an orchard sweet,

So sweet,

There is an orchard sweet.

Leaves there gleam green,

Soar, my heart, soar!

And the fruit is sweet,

So sweet.

A prince's three daughters, Soar, my heart, soar!

They sleep in there

So sweet.

The youngest wakens,

Soar, my heart, soar!

Sister, look, it's day,

So sweet.

It's only a star,

Soar, my heart, soar!

Which lights our love,

So sweet.

Our lovers go to war, Soar, my heart, soar! To war to fight for us, So sweet.

If they win the fight, Soar, my heart, soar! They will have our love, So sweet. Soar, my heart, soar! They will have our love, So sweet.

16. Recueil de chansons canadiennes et françaises: divisé en deux parties (Montréal: J. Lovell, 1859), 12-13. After the first stanza, I excise repeated phrases. The English translation is my own. 
This song became popular in the fifteenth or sixteenth century. ${ }^{17}$ It evidently comprises in its longevity, therefore, an audible token of the whole history of la Nouvelle France. Perhaps a perfect coeval of "Les trois filles d'un prince," Jacques Cartier was born in Saint-Malo in 1491, and made three expeditions to North America from that port in 1534, 1535, and 1541. Samuel de Champlain, born at Rochefort in Poitou around 1567 , would probably have heard these verses at some time. On 12 June 1792, the bateaumen must have repeated the ancient poem at the desire of their British passengers. It is literally the sound of the past made present (according to St. Augustine, the only way in which human beings can experience the past ${ }^{18}$ ). An old tune-an old talesupply the tempo and stimulus for a voyage into an idea of futurity, the one intended and cherished by the Simcoes and by the policy-makers of Whitehall.

Given the history of New France, of John Graves Simcoe, and of the United Indian Nations' resistance south of Lake Erie, pathos saturates the song's three sisters, who promise to love their beaux whatever the campaign's outcome. The new Lieutenant-Governor of Upper Canada belonged to the losing side of the American Revolution, and courted Elizabeth Gwillim in Devon's Blackdown Hills while he convalesced from malaria and from participation in the conflict. Colonel Simcoe's father, Captain of the frigate H.M. Pembroke, died of pneumonia off Anticosti Island toward the end of the Seven Years' War. And Lieutenant-Governor Simcoe was drawn into yet another illfated struggle in 1794. Lord Dorchester, his superior, first enjoined him to rebuild and garrison Fort Maumee inside U.S. territory. Then orders came not to support Little Turtle's Indigenous army after all, after General Anthony Wayne's American Legion attacked nearby. Native warriors falling back from the battlefield had been led to expect, and could not receive, the support of Major William Campbell's forces. ${ }^{19}$

17. For the French background of the song, I rely on chantgallo.com, accessed 26 August 2017.

18. Augustine, Confessions, vol. 1, trans. William Watts (Cambridge: Harvard University Press, 1977): "There are neither future nor past things... There are three tenses: the present of the past, the present of the present, the present of the future" $(11.20,252)$.

19. George Washington attacked the "irregular and high-handed proceeding of Mr. Simcoe," calling it "the most open and daring act of the British agents in America." See Alan Taylor, The Divided Ground (New York: Vintage, 2006), 284. 
Describing the recital of "Les trois filles d'un prince," Simcoe records what she calls an "Indian halloo that breaks the often repeated notes." This exclamatory punctuation acknowledges with exuberance and with plangency that the entire enterprise of the fur trade has been métis. By the 1670s, the French had extended commerce with Indigenous peoples as far as the Strait of Mackinac. The music that Elizabeth Simcoe appreciates therefore incorporates the exemplary resonance of a long practice of métissage-all kinds of mixture. As for her phrase "Indian halloo," it recurs in English-language chronicles especially from the Seven Years' War forward. During that struggle (1756-63), Indigenous allies of the French and British varied their notes to convey location, warning, triumph, salutations. Those of European descent imitated these signals. The British Lieutenant John Grant, posted to North America during the Seven Years' War, relates that, as battle broke out, "We instantly gave the Indian Halloo, part of our Backwoods aquirements." On the occasion Grant remembers, the shout instilled resolve into a wavering body of redcoats. ${ }^{20}$ On 4 April 1778, James Burney, First Lieutenant of James Cook's Discovery, then anchored in Nootka Sound and reconnoitred by the residents of that inlet, noted "several of the larger Canoes saluted us, by making a Circuit round the ships and giving 3 Halloos at their departure, they paddle in most excellent time, the foremost man every $3^{\text {rd }}$ or $4^{\text {th }}$ Stroke making flourishes with his paddle. The halloo is a single note in which they all join, swelling it out in the middle and letting the Sound die away." 21 Thus, despite the vast interval of the continent separating the Atlantic from the Pacific coast, British listeners inclined to choose the identical term to characterize Indigenous calls.

\section{Phaedria's Nest}

Having acknowledged Frances Brooke and the hybrid harmonies of New France, Simcoe directly invokes Spenser and Ariosto. The Faerie

20. See Stephen Brumwell, Redcoats: The British Soldier and War in the Americas, 1755-63 (Cambridge: CUP, 2002), 225.

21. “225 Years Ago: April-June 1778," Captain Cook Society, accessed 22 November 2017, www.captaincooksociety.com. See also, James Cook, The Journals of Captain James Cook on his Voyage of Discovery, vol. 3, part 1, ed. J.C. Beaglehole (London: Cambridge, 1967), 299. 
Queene and Orlando Furioso furnish her with antecedents (she claims) to gloss the sensation of gliding on inland waters toward "Islands of Delight." Raising a sort of memorial atoll to mark, above the surface of oblivion, her own experience, Simcoe's writing amounts to the literary analogue of such a land-form. In prizing the Renaissance poets whom she mentions, her taste matches that of some arbiters of her period. Richard Hurd in his 1762 Letters on Chivalry and Romance judged the "Gothic Romances" of "the greatest geniuses" Ariosto, Tasso, Spenser and Milton superior to Virgil's Aeneid. ${ }^{22}$ Then which passages from her poets does Simcoe seem to recall? In a Canadian milieu, with what implications might those passages be freighted? Spenser's Faerie Queene features an episode that answers richly to the requisites of Simcoe's allusion. ${ }^{23}$ This incident features the adventure of Cymochles and Phaedria. The former intemperate warlike lord (who bears a name that implies the vice of concupiscence):

Came to a riuer, by whose vtmost brim

Wayting to passe, he saw whereas did swim

A long the shore, as swift as glaunce of eye,

A litle Gondolay, bedecked trim

With boughes and arbours wouen cunningly,

That like a litle forest seemed outwardly. (II.vi.z) ${ }^{24}$

Simcoe's own painterly gaze has just swept the twilit breadth of the St. Lawrence as rapidly as Spenser's gondola. That fabulous transport conforms almost to the point of physical identity to the forest by which either bank of the woods is crowded. In design it perhaps would conciliate art with nature. Then to whom does this boat belong?

And therein sate a Ladie fresh and faire,

Making sweet solace to her selfe alone;

Sometimes she sung, as loud as lark in aire,

Sometimes she laught, that nigh her breth was gone,

Yet was there not with her else any one,

That might to her moue cause of meriment. (II.vi.3)

22. See James Sambrook, The Eighteenth Century: The Intellectual and Cultural Context of English Literature 1700-89 (London; New York: Longman, 1986), 118.

23. Edmund Spenser, The Faerie Queene, ed. Thomas P. Roche (New Haven and London: Yale University Press, 1978), II.vi. 267-79.

24. Cymochles's sensual nature inclines him elsewhere to adore in her Bower of Bliss as his "dearest Dame" the enchantress Acrasia. 
Simcoe summons, to express her Canadian experience, a figure of her own sex, alone in Siren-like alluring splendour and capable of making consolation rather than merely receiving it. Not a crew of bateaumen, but Phaedria herself sings. Her magical craft steers without assistance, like the fleet of the Phaiakians in Homer.

As for Cymochles, that amorous man-at-arms has lately shaken off the enticements of "a flocke of Damzels," stirred to avenge injuries dealt to his irascible-fiery-brother Pyrochles (II.v.32). At first adhering to his quest, the revenger hitches a ride aboard Phaedria's vessel. The "wanton" entertains him with "merry tales," immodestly "drowned with laughter" (II.vi.6). Turning her excess of "fantastic wit” to winding "gaudie girlonds," rings of rushes and flowers, the temptress disarms her passenger (II.vi.7): "Her light behauiour, and loose dalliaunce/Gaue wondrous great contentment to the knight" (II.vi.8): "So easy is t'appease the stormie wind/Of malice in the calme of pleasant womankind" (II.vi.8). The pair now embarks on what Phaedria calls the Idle Lake. They come to an island "like a litle nest,/As if it had by Natures cunning hand,/Bene choisely picked out from the rest,/And laid forth for ensample of the best" (II.vi.12). Blossoms and "fine" singing birds weigh every branch (II.vi.13). The effect, predictable enough, is to divest the warrior of his "wrathful purpose" - namely, the knightly resolve to retaliate for harm done to his brother Pyrochles.

Spenser's writing becomes even more plainly erotic as Phaedria takes the knight's head "In her loose lap"-Cymochles elsewhere likes to "entomb" himself in that happy location (II.v.36) - while she sings him a song advocating indolence in the bosom of spontaneous Nature. In Simcoe's context, the theme of sloth or leisure chimes with Arabella Fermor's ironically energetic vow to erect a temple to the goddess of laziness at Montmorenci. Echoing the Sermon on the Mount but wresting its sense, Phaedria instances the example of "The lily, Lady of the flowering field," who does not toil or spin, urging on Cymochles the indulgence of "present pleasures" (II.vi.16). In his 1758 annotation of the Faerie Queen, John Upton emphasizes Phaedria's capacity "to shew how the best of sayings may be perverted to the worst of meanings." 25 Like a sojourner among the Lotos-Eaters, Cymochles

25. John Upton, Notes on the Fairy Queen, vol. 1, ed. John G. Radcliffe (New York: Garland, 1987), 454. 
lapses into sleep with "the Ladie debonaire" (II.vi.28). For Elizabeth Simcoe, Spenser's fantasy could affirm a vision of female power-of aesthetic power too. Her own artistic strength endures in the serial remainder (illustrations, journal) that she created with pen and brush over the course of what was a journey and a stay subdued otherwise to the insistencies of earnest diplomatic necessity. As for female as distinct from aesthetic power, such was Simcoe's influence on her husband that a fellow colonist, Hannah Jarvis, denounced the Lieutenant-Governor of Upper Canada for submitting to "petticoat rule." ${ }^{26}$ As prone to song as Circe and Calypso, Phaedria in her ornate boat and bower may thus in some measure serve as a projection of Elizabeth Simcoe's personal charm and ability. The sybaritic lord Cymochles, too little invested in a defence of fraternal honour, may, on the other hand, embody-like the world of Spenser at large-an object lesson in the necessity of persisting in dutifulness, the abstract burden of a higher quest. Spenser's immense wildwood has its extensive counterpart in British North America. What about Ariosto's cosmopolitan Orlando Furioso and islands, then?

\section{Alcina's Myrtle, Sophrosina's Mind}

Celebrated by Handel in opera, the sorceress Alcina famously occupies an island. Duke Astolfo, an Englishman fleeing Alcina's magic and assisted by Logistilla, Andronica and Sophrosina:

sail'd along that Indian shore,

And sees and leeseth sight of sundrie Iles,

Those called fortunate and others more,

That distant are, some few, some many miles,

And (for he never heard of them before)

He askt his guide some questions other whiles,

As whether from those Indian seas perchance

A ship may saile to England, Spain, and France. (15.12)

In the midst of that "fortunate" archipelago, Sophrosina answers:

to put you out of doubt,

First know the earth it selfe is like an Iland,

Invironed with waters round about, 
That compasse in on ev'ry side the drie land, And though to this day no man hath found out,

Nor thinks there can be any way but by land,

Because they judge the lands length there is such,

That it the other Hemispher doth tuch. (15.13)

The learned Sophrosina goes on accurately to prophesy that "New marriners and masters new shall rise ... To find new lands, new starres, new seas, new skies" (15.14). As in Spenser, Ariosto's female figures dominate the heroes whom they influence. This time such personnel do not only seduce, but also protect and guide their masculine counterparts. John Harington in 1591 interprets Andronica and Sophrosina as allegories of fortitude and temperance. ${ }^{27}$

Earlier, however, when the handsome Duke Astolfo found himself beached on Alcina's isle of delight, the sorceress chose him for her latest consort (6.33). Tiring of him, as of all her suitors, Alcina changes Astolfo into a myrtle, a shrub sacred to Venus. She in fact afforests her whole domain with metamorphosed beaux. At last Melissa, a witch, does release Astolfo from his vegetable detention (8.16). Now Sophrosina pilots the Duke through the island-dotted Indian Ocean and (as this cruise unfolds) utters a prediction that Elizabeth Simcoe's own experience bears out. ${ }^{28}$ For, from Ariosto's Mediterranean perspective of 1530 , the country round the St. Lawrence does qualify as a "new land." Spenser's Faerie Queene has supplied the vision of a musical waterborne temptress and a lord more lustful than vengeful. With Sophrosina, Ariosto depicts instead a female incarnation of rational intellect.

The disparate figures (Phaedria, Sophrosina, Alcina), blended with Brooke's coquette Arabella Fermor, with the rowers' royal daughters of Brittany and the country wives of Michilimackinac, tint Elizabeth Simcoe's rendering of the St. Lawrence River with many shades of womanly possibility, womanly action. Phaedria embodies unregenerate nature, and with it the possibility of renouncing the ancient chivalric

27. Ibid. 174 .

28. Alcina's is definitely an "island of delight," as first glimpsed by Rogero mounted on his "Griffeth horse" (6.18); "A fairer place they saw not all the while ... In all the world was not a fairer ile" (6.20). It features "Cleere rivers, shadie banks, and meddowes faire" (6.20). 
system altogether ${ }^{29}$; Sophrosina the reality that (as Mary Wollstonecraft puts the matter, in Simcoe's year 1792) women possess, like men, "the gift of reason" 30 ; Alcina female lust and the female capacity to objectify men as men have objectified women; Arabella Fermor the right of a woman to relish her wit and to choose her partner freely; the prince's daughters the persistence of love beyond any political defeat; and the country wives of the Pays-en-Haut the ingenious energy of what custom castigates as wild, abject, inferior and impure.

\section{Armida and the Enchanted Wood}

So far Elizabeth Simcoe's Diary has adduced two Renaissance epicists. There remains a third: Torquato Tasso (1544-95), famous for his 1575 heroic poem Gerusalemme Liberata (Jerusalem Delivered), set during the First Crusade (1095-99). Simcoe names Tasso in this journal entry of 7 July 1792. She records the day before her husband took his gubernatorial oath at St. George's Church in Kingston, Upper Canada. In her diary, Simcoe probably apostrophizes her friend Mary Anne Burges:

I walked this Evening in a wood lately set on fire, by some unextinguished fires being left by some persons who had encamped there; which in dry weather often communicates to the Trees. Perhaps you have no idea of the pleasure of walking in a burning wood, but I found it so great that I think I shall have some woods set on fire for my Evening walks. The smoke arising from it keeps the Musquitoes at a distance \& where the fire has caught the hollow trunk of a lofty Tree the flame issuing from the top has a fine effect. In some trees where but a small flame appears it looks like stars as the Evening grows dark, \& the flare $\&$ smoke interspersed in different masses of dark woods has a very picturesque appearance a little like Tasso's enchanted wood. (72)

Elizabeth Simcoe's comic-even heedless-capacity to kindle her delight wherever she can glows in this celebration of the experience of

29. See, for example, Elizabeth Mazzola, "Ethical Dilemmas and Romance Destinations: 'Pigeonholes of Oblivion' in 'The Faerie Queene,' Book II," Huntington Library Quarterly 61.1 (1998): 29-52.

30. Writing to Charles Maurice de Talleyrand-Périgord, Mary Wollstonecraft asks,"Who made man the exclusive judge, if woman partake with him the gift of reason?" Mary Wollstonecraft, A Vindication of the Rights of Woman, ed. Carol H. Poston (New York: Norton, 1975), 5. 
a forest fire. What is "Tasso's enchanted wood" and what meanings might it incidentally express for the diarist? She probably relied on Edward Fairfax's 1600 translation of the 1581 epic. ${ }^{31}$

Duke Godfrey of Bouillon's army has encamped near Jerusalem. In order to challenge the Saracen defenders of the city, his Christian forces need lumber to replace numerous destroyed siege-works. But the Satanic warlock Ismeno controls the Wood of Sharon. This wizard summons infernal angels to occupy his forest. A daemon possesses every tree. After the rest of the Christian woodcutting detail, spooked by Ismeno's occult wardens, has retreated, Alcasto the Switzer alone "scorn'd the perill" (13.26). Ismeno and his spirits confront this man with a wall of flame: "strange monsters on the battlement/In loathsome forms stood to defend the place" (13.28). Alcasto can only flee unnerved, "Amas'd, asham'd, disgras'd, sad, silent, trist" (13.29). But, in 1792, Elizabeth Simcoe replaces the Switzer's disgrace with gusto. Her smouldering forest's smoke routs the local goblins-Canada's blooddrinking bugs.

In Tasso, Tancred manages to breach the spectral barrier of Ismeno's sylvan redoubt. He reports, "Of monsters foul misshapt whole bands appeared;/But through them all I past, vnhurt, vnharmed" (13.48). But Tancred dismayingly discovers that the bewitched trees bleed whenever he rips their branches. ${ }^{32}$ Then he seems to hear the plaint of his lost beloved, Clorinda. Here a world affined to Phaedria and Alcina's emerges - sexy, mutable, deceitful, and intense. Clorinda does not really suffer in Ismeno's groves. A daemon impersonates her. It takes a third man, great Rinaldo, to dispel at last the prohibitive magic of the Enchanted Wood. Defying the pyrotechnics and the monstrous watch, he enters a pleasaunce in the heart of the forest where the enchantress Armida would appear to abide, attended by fully one hundred nymphs wantoning in a ring, their dresses hoisted above their knees, their tresses loose, their arms bared (18.26-32). Yellow-

31. On 15 April 1792, Simcoe assimilates the diction of an Indigenous interlocutor to the world of Renaissance epic: "An Indian who speaks English being asked at what hour he arrived, pointed to the West \& said 'when the Clock was there.' It reminded me of a line in Spencer, 'The clock in Jove's high House' (93). In fact, Spenser does not mention a "clock." Nor does Tasso. But Simcoe may paraphrase either epicist. They use in common, in English translation, the phrase "Jove's high house."

32. The precedent is likely Polydorus in Virgil's Aeneid. Condemned by Alcina to myrtle form, Ariosto's Duke Astolfo suffered in the same way. 
haired Armida pleads, "Kisse me, embrace me... Love keepes the gate" (18.32). Her mission is to distract him from another gate, Jerusalem's: the proper object of Rinaldo's quest. Once the Crusader rejects the enticing likeness of Armida, she cycles through a series of intimidating apparitions-a giantess, a cyclops. Ignoring these vain phantasms, Rinaldo hews down the vast myrtle, emblem of Venus, on which the forest's protection depends: "Then [flee] the spirits all, the charms all ended" (18.37). Assimilating herself bodily to "sensuous, Ovidian nature," 33 Armida pleads:

Ah, neuer do me such a spitefull part,

To cut my tree, this forrests ioy and pride,

Put vp thy sword, else pierce therewith the hart

Of thy forsaken and despis'd Armide;

For through this brest, and through this hart (vnkind)

To this faire tree thy sword shall passage find. (18.34)

Now Tancred's crusading army can exploit to the full Saracen Ismeno's immemorial cedar stand. ${ }^{34}$

What could such a story signify for Elizabeth Simcoe? In 1792, the environs of Kingston support a mixture of Loyalists, French Canadians, Mississauga people and Six Nations or Haudenosaunee. In the judgment of her husband, the Lieutenant-Governor, the place lay too close to the U.S.A. safely to be the capital of Upper Canada, despite the lobbying of Richard Cartwright and the rest of Kingston's entrenched merchants. The Lieutenant-Governor feared the ease of winter invasion over lake-ice. Ideas of Graeco-Roman paganism (complete with Venus and Pluto), mingled with recollections of mediaeval Islam and militant Christianity, form, in Simcoe's allusion to Tasso, a fantastical overlay on North American terrain still contested by hot factions precariously friendly and hostile. When Elizabeth Simcoe does depreciate some Mississauga men whom she encounters-and she often other-

33. Andrew Fichter, “Tasso's Epic of Deliverance," PMLA 93.2 (1978): 265-74, 266. Recall how Astolfo became a myrtle in Alcina's insular grove.

34. In book 14 of Jerusalem Delivered, the witch Armida sings Rinaldo to sleep with the aim of killing him on her enchanted isle in the River Orontes. But even as she raises the knife, the sight of him becalms her wrath. The slumbering warmth of his hidden eyes charms her-a scene Nicolas Poussin immortalized in a painting of 1625, featuring a red-haired, bare-bosomed Armida. 
wise favours Indigenous acquaintances - it is on the revelatory grounds of their seeming "unwarlike" (72). . $^{35}$

Spenser's Phaedria, like Alcina, incarnates female enchantment; Ariosto's Sophronisa female wisdom; and Tasso's Armida a beguiling by-form or votary of a love-goddess. But Tasso especially emphasizes the reciprocity of fear with the power of magic. A true Christian resists superstition, and proceeds coolly to the pragmatic exhaustion of available natural resources; ignores a flimsy cordon of flame surmounted by faux ghouls; and overthrows instead a real city wall-Jerusalem's. The equal of heroes Tancred and Rinaldo, Simcoe can walk, in July 1792, through an "enchanted wood," impervious to the primordial peril of fire. She even encourages the risk. Like a woman re-reading Jerusalem Delivered for pleasure, she would repeat, at will, the experience of a conflagrant forest, duly tempered by the picturesque. It is apparent in her dream of repetition-sister to her demand on the St. Lawrence that the bateaumen repeat the song "Les trois filles d'un prince"-Simcoe does not want particularly to get to the part of Tasso's epic when, the myrtle felled, unlovely disenchantment will disfigure Ismeno's wilderness. In her arch confession of pyromania, Simcoe professes, like Armida, a burning beauty of mind (see Gerusalemme 16.18: the Italian is mente accesa; pensier ardenti ${ }^{36}$ ). Yet, in her account of a stopover in Kingston, she contradictorily expresses delight in the "progress of Industry" as she witnesses "neat" houses rising beside log huts (73). ${ }^{37}$ On 7 July 1792, however, Simcoe nevertheless prefers a time before the destruction of the aromatic shrub sacred to Venus and before the ugly distortion of love-sick Armida's form. In this mood she may construe Tasso's poem against its grain. Although Simcoe consciously favours and would foster settlement, she adores a haunted wildwood. Who or what haunts it? Arguably aboriginality, insofar as she can glimpse it under the sign of opulent romance, of beauty and sublimity. Elizabeth Simcoe would befriend-or at least salute-a terrifically glamorous elemental indwelling numen.

35. She adds that they manifest "the apparent Nonchalance, want of occupation \& indifference that seems to possess Bond street Beaux" (72).

36. See Fichter 266.

37. 13 July 1792. She has just described the process of girdling "Heavier Timber," noting "the very large leafless Trees have a singular \& sometimes a picturesque effect among the living trees" (73). 
The diarist's enthusiasm for Spenser, Ariosto and Tasso broadly conforms to the taste of her period. Thomas Warton the younger's Observations on The Faerie Queene of Spenser (1754) urges readers of that poem to derive pleasure from its depiction of "appearances, which are utterly different from those with which we are presently surrounded." 38 For Simcoe, Canada itself is pretty "utterly different"-and it very "presently" surrounds her. In 1788, Henry Fuseli painted Prince Arthur's Vision in oils for Thomas Macklin's Poets Gallery. Macklin selected the topic for Fuseli because Spenser had the reputation of being the "poet of painters." 39 Gloriana (blue-sashed, barefoot, white-robed, glowing) looms over a shadowy Arthur, who slumbers in armour. Had Fuseli got hold of Simcoe's accurate sketches of Lower and Upper Canada, he could with excuse have populated them with the sprites and daemons, the daydreams and nightmares that were his destiny and his specialty. Such an intervention might appear illegitimate-except the evidence of Simcoe's Diary is that her Gilbert White-like engagement with responsible natural history and her dedication to a workable model of British rule in North America coexist with hospitality to the splendours of romance or of what G.K. Chesterton calls "the mysticism of happiness." ${ }^{40}$ She loves to apprehend the Canadas by the magic of such fitful lights. Simcoe's piquancy issues from a shifting amalgam of Virgilian dutifulness, empirical curiosity and visionary volupté. Her disposition is to compose an aesthetic idyll, a vision of beautiful unity, of unified beauty, in confessed tension with discomfort and an epic allowance for struggle, death, illusion, destruction, misprision, diaspora, and disappointment. Edmund Spenser assisted at the bloody reduction of Ireland; Ludovico Ariosto's hero Orlando, though his wits were restored to him, never won his Angelica; and Tasso's Jerusalem was delivered, in 1187, into the hands of the magnanimous Saladin. As a reader and sometimes as a writer, Elizabeth Simcoe already knows that to found a colony is to begin to lose it.

38. Thomas Warton, Observations on The Faerie Queene of Spenser (London: R. \& J. Dodsley \& J. Fletcher, 1754), 218.

39. Luisa Calè, Fuseli's Milton Gallery: “Turning Readers into Spectators” (Oxford: Clarendon, 2006), 75 .

40. G.K. Chesterton, The Bodley Head G.K. Chesterton, ed. P.J. Kavanaugh (London: Bodley Head, 1985), 59. 